\section{Benzyladenine and Gibberellic Acid Increase Runner Production in Dayneutral Strawberries}

\author{
Adam Dale \\ Horticultural Research Institute of Ontario, Box 587, Simcoe, Ontario N3Y \\ 4N5, Canada
}

Don C. Elfving ${ }^{1}$

Tree Fruit Research and Extension Center, Washington State University, 1100 North Western Avenue, Wenatchee, WA 98801

Craig K. Chandler

Agricultural Research and Education Center, University of Florida, 13138 Lewis Gallagher Road, Dover, FL 33527

Additional index words. Fragaria $\times$ ananassa

Abstract. In greenhouse and field studies, benzyladenine (BA) and gibberellic acid $\left(\mathbf{G A}_{3}\right)$ applied together as a foliar spray increased runner production in dayneutral strawberries (Fragaria $\times$ ananassa Duch.) but not when applied separately. Runner production increased linearly with increased $B A$ concentration to $1800 \mathrm{mg} \cdot \mathrm{L}^{-1}$. At high dosages, $\mathbf{G A}_{3^{-}}$ treated plants produced elongated internodes that, in the field, led to fewer daughter plants. In Florida, daughter plants derived from plants sprayed with the growth regulators increased yield by up to $10 \%$ in fruiting experiments. To induce runnering in the field and greenhouse, a treatment with $B A$ at $1200 \mathrm{mg} \cdot \mathrm{L}^{-1}$ and $G A_{3}$ at $300 \mathrm{mg} \cdot \mathrm{L}^{-1}$ is recommended. Chemical names used: $N$-(phenylmethyl)- $1 H$-purine-6-amine (benzyladenine); gibberellic acid $\mathrm{A}_{3}$; gibberellic acids $\mathrm{A}_{4}$ and $\mathrm{A}_{7}$.

Dayneutral strawberries produce flowers and fruit continually during the growing season and, therefore, produce stolons (runners) sparsely (Pritts and Dale, 1989). In propagation fields, this behavior results in fewer daughter plants than in June-bearing strawberries. More daughter plants can be obtained if coldstored, tissue-cultured plants are used (Cameron et al., 1985; Scott et al., 1985). However, this enhanced effect of tissue culture declines after about 2 years.

Growth regulators (PGR) can induce runners to form either by stimulating dormant buds to grow or by preventing flower bud initiation (Pritts et al., 1986; Reid, 1983). Gibberellic acid $\left(\mathrm{GA}_{3}\right)$ has increased runner production inconsistently (Reid, 1983). Cytokinins, such as benzyladenine (BA) and tetrahydropyranyl-benzyladenine (PBA) also have shown inconsistent results when applied alone (Kender et al., 1971; Pritts et al., 1986; Waithaka and Dana, 1978). When used in combination, cytokinins and $\mathrm{GA}_{3}$ markedly enhanced stolon formation on the everbearing

\footnotetext{
Received for publication 19 Dec. 1995. Accepted for publication 18 June 1996. We gratefully acknowledge the technical assistance of John Zandstra. The cost of publishing this paper was defrayed in part by the payment of page charges. Under postal regulations, this paper therefore must be hereby marked advertisement solely to indicate this fact. ${ }^{1}$ Formerly Manager, Research Programs, Horticultural Research Institute of Ontario, Box 7000, Vineland Station, Ont., Canada.
}

'Geneva' and 'Ozark Beauty' (Kender et al., 1971; Waithaka and Dana, 1978) and on the June-bearing 'Nyoho', 'Morika-16', and 'Hokowase' (Kahangi et al., 1992). We are not aware of any such studies on dayneutral cultivars.

This study was done to test the individual and possibly synergistic effects of benzyladenine and gibberellic acid on runner production in dayneutral strawberries, to produce a practical application for use commercially, and to test for any residual effect of the growth regulators on runner plant performance.

\section{Materials and Methods}

Preliminary experiments were done in a heated greenhouse at the Horticultural Experiment Station, Simcoe, Ont., to assess the effects of various concentrations of growth regulators on runner production. Commercial-scale trials were carried out in the strawberry propagation fields of Strawberry Tyme Farms, Simcoe, Ont. Daughter plants from the commercial trials were fruited at the Univ. of Florida, Agricultural Research and Extension Center, Dover. The growth regulators used were proprietary formulations (Abbott Laboratories, North Chicago, Ill.) of BA (ABG3062), $\mathrm{GA}_{3}$ (ProGibb), equimolar $\mathrm{GA}_{4}$ and $\mathrm{GA}_{7}\left(\mathrm{GA}_{4+7}, \mathrm{ABG}-3035\right)$, and equimolar $\mathrm{GA}_{4+7}$ and BA(Promalin). Single plants were sprayed to runoff with $25 \mathrm{~mL}$ of the treatment solution.

Type of PGR, greenhouse (Expt. 1). This initial study was to test effect of several growth regulators on runner production in the green- house. The concentrations used were based on those used in previous strawberry growth regulator studies (Kender et al., 1971; Pritts et al., 1986).

Field-grown 'Tribute' plants were potted into $1.9-\mathrm{L}$ pots in a 1 peat : 1 sand : 1 soil mix (by volume) in Sept. 1989. The plants were at least four generations away from tissue culture. On 1 Mar. 1990, the plants were sprayed with various growth regulators. Five plants were sprayed for each treatment and then placed in a heated greenhouse in 16-h days in a completely randomized design. The last fully expanded leaf was tagged on one crown in each pot before being sprayed so that the origin of new runners could be determined.

The growth regulator treatments (a.i. $\mathrm{mg} \cdot \mathrm{L}^{-1}$ ) were 1) none (control); 2 and 3) BA alone at 300 or $600 ; 4$ through 7) $\mathrm{GA}_{3}$ or $\mathrm{GA}_{4+7}$ each, at 100 or 200 ; and the combinations, 8 and 9) $\mathrm{GA}_{3}$ at 100 with BA at 300 or 600 ; and 10 and 11) $\mathrm{GA}_{4+7}$ at 100 with $\mathrm{BA}$ at 300 or 600 .

The number of runners per plant was recorded weekly. At the end of the experiment, 16 May 1990, the tagged crowns were examined to see whether the buds at the nodes had runnered, flowered, or remained dormant.

PGR concentrations, greenhouse (Expt. 2 ). Since the first experiment showed that 'Tribute' would produce runners when growth regulators were applied to plants, this experiment was designed to find out whether the single growth regulators worked at higher concentrations or whether a combination was needed, and whether repeat applications increased the effect.

For one growth regulator treatment we wanted to use a GA/BA formulation [Promalin $\left.\left(\mathrm{GA}_{4+7}\right)+\mathrm{BA}\right]$ that was already registered on some crops for ease of future registration for strawberries. According to Expt. 1 and the literature (Kender et al., 1971), $\mathrm{GA}_{3}$ appeared more effective than $\mathrm{GA}_{4+7}$, so we used $\mathrm{GA}_{3}+$ $\mathrm{BA}$ as a parallel series to Promalin. The treatments (a.i. $\mathrm{mg} \cdot \mathrm{L}^{-1}$ ) used were none (control); BA alone at 600,1200 , or 1800 ; $\mathrm{BA}$ and $\mathrm{GA}_{4+7}$ combined, i.e., Promalin at 600,1200 , or 1800 of each constituent; and BA and $\mathrm{GA}_{3}$ combined, each at 600,1200 , or 1800 . The growth regulators were applied once or twice with separate controls for each.

The same 'Tribute' plants used in the first experiment were split, repotted, allowed to resume their normal floriferous growth habit, and then used for this experiment. On $12 \mathrm{Feb}$. 1991,10 plants were treated, five of these were sprayed again with the same treatment on 26 Feb. 1991. All plants were then placed in a heated greenhouse with 16-h days in a completely randomized design.

The last fully expanded leaf was tagged on one crown in each pot before being sprayed. The number of runner plants per crown was counted on 15 Apr. 1991 and the tagged crowns examined.

PGR concentration on 'Selva', greenhouse (Expt. 3). As the most commonly propagated dayneutral strawberry cultivar was 'Selva', we tested the effect of the growth regulators on this cultivar before initiating field tests. Because the internodes elongated at high concen- 
trations, slightly lower concentrations were used to find suitable ones for the field. Also $\mathrm{GA}_{3}$ alone was used to check that the response is not just a response to $\mathrm{GA}_{3}$.

Cold-stored 'Selva' plants were planted in pots on 12 Mar. 1991 in the greenhouse and treated on 9 Apr. 1991. Five pots were used per treatment and completely randomized within the greenhouse. The number of runner plants per crown were counted on 30 May 1991.

The treatments (a.i. $\mathrm{mg} \cdot \mathrm{L}^{-1}$ ) used were none (control); $\mathrm{GA}_{3}$ at 600,900 , or $1200 ; \mathrm{BA}$ at 600 , 900, or 1200; and $\mathrm{GA}_{3}$ and BA combined, each at 600,900 , or 1200 .

PGR combinations and concentrations, field (Expt. 4). This experiment was to determine runnering using growth regulators under field conditions and to check carry-over effects on yield. The concentrations of growth regulators used were those that gave optimum runnering in Expt. 3.

Runner plants of 'Selva' were grown from freshly dug, overwintered plants and planted 8 May 1991. They were grown in a commercial propagation field according to the guidelines of the Ontario Strawberry Plant Propagation Program (Dale and Vandenberg, 1989).

The PGR treatments (a.i. mg. $\mathrm{L}^{-1}$ ) were none (control); $\mathrm{GA}_{3}$ at 600 or $900 ; \mathrm{BA}$ at 600 or 900 ; and $\mathrm{GA}_{3}+\mathrm{BA}$ each at 600 or 900 . Applications were made once (7 June 1991) or twice (on 7 June and 5 July 1991). There were five replications of each treatment laid out in a randomized complete-block design. Plots consisted of 10 plants covering $3 \mathrm{~m}$ of row and $1 \mathrm{~m}$ between plots. All plots were in a single row.

Plants were dug on 2 Oct. 1991, cold stored overnight, and cleaned and sorted the following day. The number of saleable runner plants per plot was counted and the crown diameter of 10 runner plants per plot measured. A saleable plant was one that had a minimum crown diameter of $8 \mathrm{~mm}$ and at least 10 roots $\geq 75 \mathrm{~mm}$ long.

Twenty-five saleable plants per plot were then shipped to Florida, where the plots were replanted in a randomized complete-block design and grown according to the Florida cultural system. Yield and fruit weight were recorded throughout the harvest season.

Combination of $\mathrm{GA}_{3}$ and BA, field (Expt. 5 ). Evidence from the greenhouse indicated that the combination of $\mathrm{GA}_{3}$ and BA stimulated runnering, but in the field in 1991, fewer saleable plants were produced on mother plants treated with the combination than on the controls. However, we believed that the internode elongation shown by plants treated with high concentrations of $\mathrm{GA}_{3}$ was masking the stimulatory effects in the field. The low concentrations of $\mathrm{GA}_{3}$ used in Expt. 1 indicated that the stimulatory effect could be achieved, and elongated internodes avoided, with lower $\mathrm{GA}_{3}$ concentrations. Also, the previous experiments indicated that runner production could be increased with higher BA concentrations. This experiment was designed to find out what would be an acceptable combination of low $\mathrm{GA}_{3}$ dose with higher BA concentrations than in Expt. 4.
The design was a similar randomized complete-block design as in Expt. 4 with 'Selva' plants sprayed once or twice, except that the PGRs (a.i. $\mathrm{mg} \cdot \mathrm{L}^{-1}$ ) used were none (control), $\mathrm{BA}$ at 900 or 1200 , alone or in combination with either 100 or $300 \mathrm{GA}_{3}$. Plants were set 19 May 1992 and sprayed either once (22 June 1992 ) or twice (22 June and 20 July 1992). Plants were dug on 23 Sept. 1992 , stored at $2{ }^{\circ} \mathrm{C}$ overnight, and cleaned the following day. Plants produced from the single-application plots were shipped to Florida for yield trials as in Expt. 4.

Experiment $5 a$. This experiment was done to confirm the findings of Expt. 5 on the concentrations of BA and $\mathrm{GA}_{3}$. Since the second spray of PGRs reduced saleable runner plant production, it was omitted from this experiment.

The experiment was a randomized complete-block design similar to that of Expt. 4, also with 'Selva' plants, except that there were eight replications of 10 plants each. Plants were sprayed only once, as follows (a.i. $\mathrm{mg} \cdot \mathrm{L}^{-1}$ ): none (control), BA alone at 900 or $1200, \mathrm{GA}_{3}$ alone at 100 or 300 , and all four combinations of BA with $\mathrm{GA}_{3}$.

Plants were set 17 May 1993, sprayed on 17 June 1993, dug on 20 Sept. 1993, cold stored at $2{ }^{\circ} \mathrm{C}$ overnight, and cleaned the following day.

Statistical analyses. Plot values or means were used for analysis of greenhouse experiments. In the field experiments, the data were reduced to plot means, which were used for all subsequent analyses.

Data were tested, as appropriate, by analysis of variance (ANOVA) with mean separation by Duncan's multiple range test or by regression analysis. The regression model used was similar to that described by Elfving and Allen (1987), where the response $\left(\mathrm{Y}_{\mathrm{ijk}}\right)$ to the ith timing at the jth concentration and the kth block was

$Y_{i j k}=a+t_{k}+b_{1 i} X_{j}+b_{2 i} X^{2}{ }_{j}+e_{i j k}$,

where $X_{j}$ is the jth growth regulator concentration; $t_{k}$ is the effect of block $k$; a represents the mean response without growth regulator applications; $b_{1 \mathrm{i}}$ and $b_{2 \mathrm{i}}$ are the linear and quadratic polynomial regression coefficients, respectively; and $\mathrm{e}_{\mathrm{ijk}}$ is the random error term. Graphically, the model represents a series of curves, one for each timing, radiating from a common intercept, a.

When the quadratic coefficients $\left(b_{2 i}\right)$ were not significantly different from zero, the model was refitted with these terms set to zero. When two or more curves were not significantly different from one another, a common curve was fitted. For the final curves fitted, the standard errors of the linear $\left(\mathrm{SE}_{\mathrm{b} 1}\right)$ and quadratic $\left(\mathrm{SE}_{\mathrm{b} 2}\right)$ polynomial regression coefficients were calculated. All analyses were carried out using either the ANOVA or General Linear Models (GLM) procedures of the SAS program package, version 6.03 (SAS Inst., Cary, N.C.)

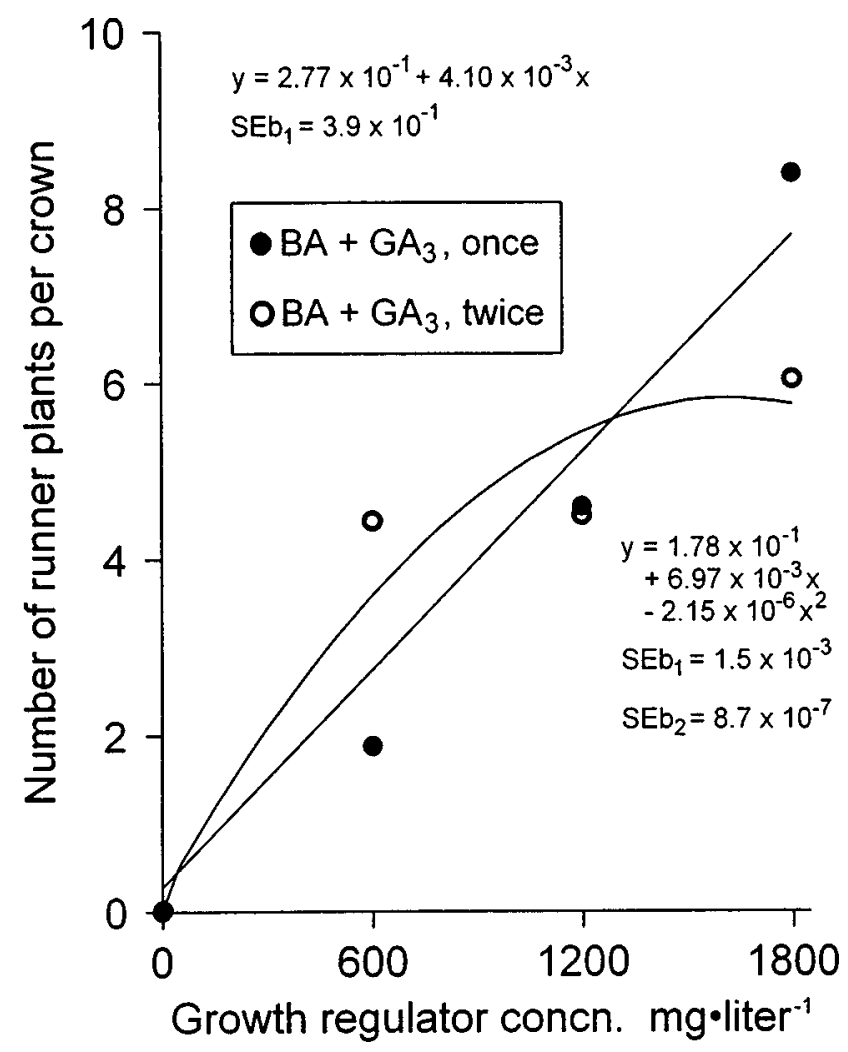

Fig. 1. Runner plant production in 'Tribute' dayneutral strawberry on 15 Apr. 1991 after treatment with BA and $\mathrm{GA}_{3}$ in various combinations once (12 Feb. 1991) or twice (12 and 26 Feb. 1991) (Expt. 2). The BA alone and $\mathrm{BA}$ and $\mathrm{GA}_{4+7}$ treatments did not differ from the control and are not presented. The regression lines given differ significantly from each other. 


\section{Results}

Experiment 1 . Only $\mathrm{GA}_{3}$ at $100 \mathrm{mg} \cdot \mathrm{L}^{-1}+$ $\mathrm{BA}$ at $600 \mathrm{mg} \cdot \mathrm{L}^{-1}$ induced significant runner formation (1.4 per crown) in almost all plants. Among the other treatments, there were from 0 to 0.4 runners per crown. The tagged crowns showed that the treated plants reverted to flowering after the initial stimulus of the $\mathrm{GA}_{3}$ and BA.

Experiment 2. Only the $\mathrm{GA}_{3}+\mathrm{BA}$ combinations promoted runner production (data not shown). Plants treated with $\mathrm{GA}_{3}+\mathrm{BA}$ increased their runner production as the PGR concentration used increased (Fig. 1). A similar effect was found when $\mathrm{GA}_{3}+\mathrm{BA}$ were sprayed twice, but the effect decreased at higher concentrations.

Runners induced by $\mathrm{GA}_{3}+\mathrm{BA}$ originated from above and below the tagged node. Above the tagged node, the internodes of the crown itself elongated and the terminal node of the crown often became a runner.

Plants treated with $\mathrm{GA}_{4+7}$ did not produce more runners than the nontreated controls.

Experiment 3. Although plants sprayed with any of the PGRs produced more runner plants than the nontreated controls, only those treated with $\mathrm{GA}_{3}$ plus BA gave a significant linear response to increased dosage (Fig. 2). Again, the $\mathrm{GA}_{3}$ treated plants produced markedly elongated internodes.

Experiment 4. Regression analysis for number of saleable plants showed significant linear interactions between PGR concentration and combination and number of sprays (Fig. $3)$. Plants treated with BA alone produced more runner plants than the controls, whereas those treated with $\mathrm{GA}_{3}$ either alone or with $\mathrm{BA}$ had similar runner plant counts as the controls when sprayed once and significantly fewer when sprayed twice. All plants that were sprayed twice had runner plants that were smaller than the controls (Fig. 4).

All plants treated with $\mathrm{GA}_{3}$ produced elongated internodes. Runner plants on such internodes were frequently unable to root and grow since the erect, elongated main stem held the runner plants above the soil.

All runner plants derived from plants treated with the PGRs applied either once or twice had significantly improved marketable yield and berry weight than the controls. Marketable yield was 7.7, 8.3, $8.3 \mathrm{~kg} /$ plot, $(P \leq 0.05)$, and mean berry weight $14.4,14.9,15.0 \mathrm{~g}(P \leq$ 0.001 ) for $0,600,900 \mathrm{mg} \cdot \mathrm{L}^{-1}$ of growth regulators, respectively. The marketable yield and mean berry weight of runner plants sprayed with the three growth regulator combinations, at the two timings, and their interactions did not differ significantly.

Experiment 5. All PGR-treated plants had more runner plants and smaller crown diameters than the control (Table 1). Plants treated with BA produced significantly more runner plants when also treated with $\mathrm{GA}_{3}$. There also were significant effects of the number of sprays on the number of saleable plants, total number of plants, crown diameter, and percent saleable plants (Table 2). There were no significant interactions between number of sprays

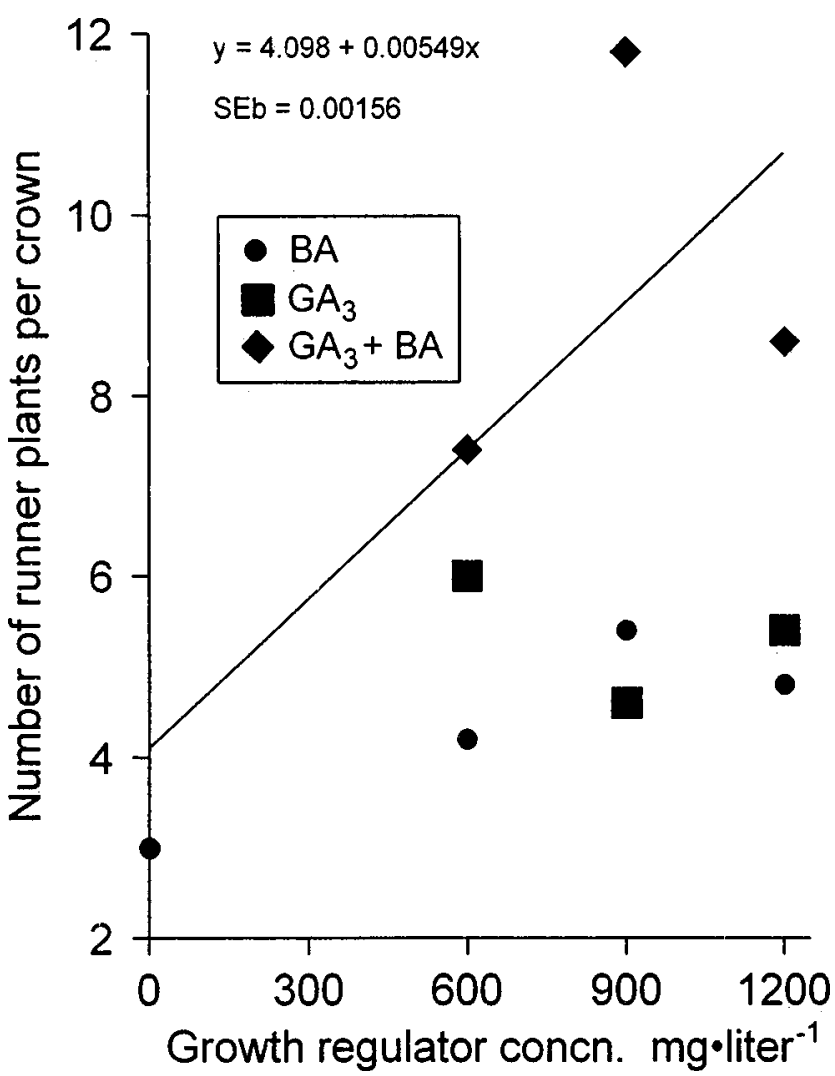

Fig. 2. Runner plant production in 'Selva' dayneutral strawberry on 30 May 1991 after treatment with BA and $\mathrm{GA}_{3}$ in various combinations on 9 Apr. 1991 (Expt. 3). The regression line for $\mathrm{GA}_{3}$ and BA differs significantly from that for the other treatments (not shown).

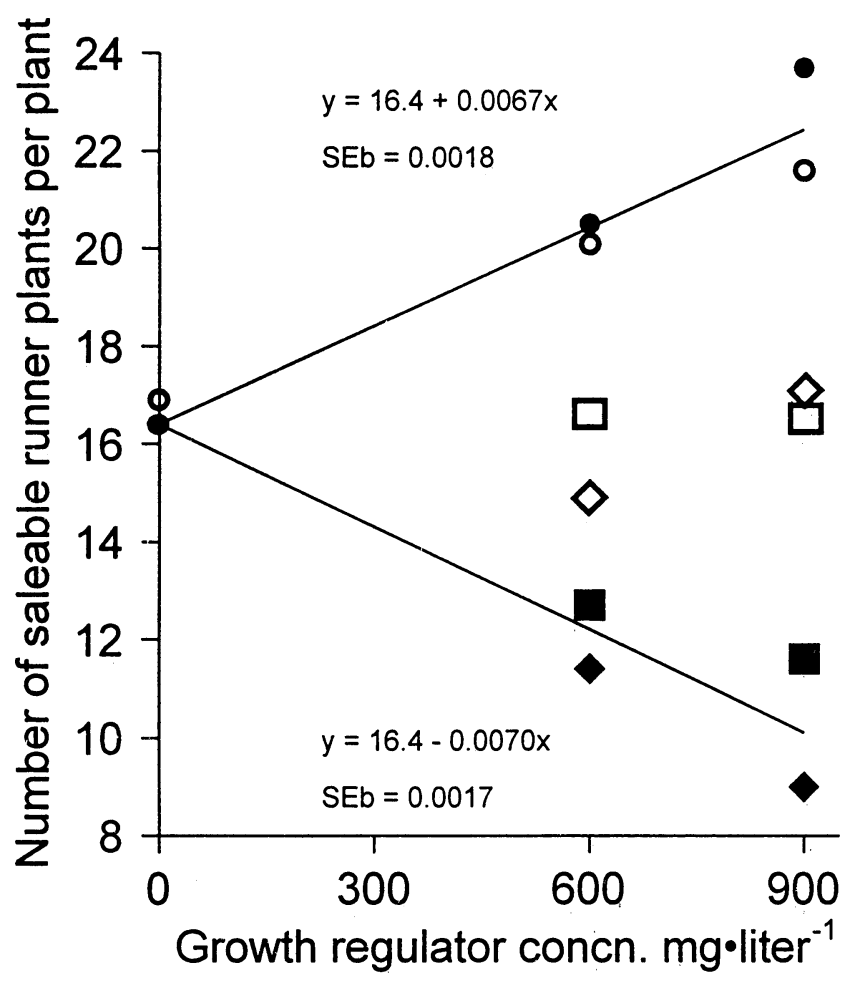

Fig. 3. Saleable plant production of 'Selva' strawberry on 2 Oct. 1991 after treatment once or twice with BA and $\mathrm{GA}_{3}$ in various combinations (Expt. 4). Circles are means for $\mathrm{BA}$, diamonds for $\mathrm{GA}_{3}$ and squares for $\mathrm{GA}_{3}+\mathrm{BA}$. Open symbols are means for sprayed once, closed symbols twice. The regression lines given are for $\mathrm{BA}$ alone sprayed once and twice and for $\mathrm{GA}_{3}$ alone or with $\mathrm{BA}$, sprayed twice. They are differ significantly from each other. 


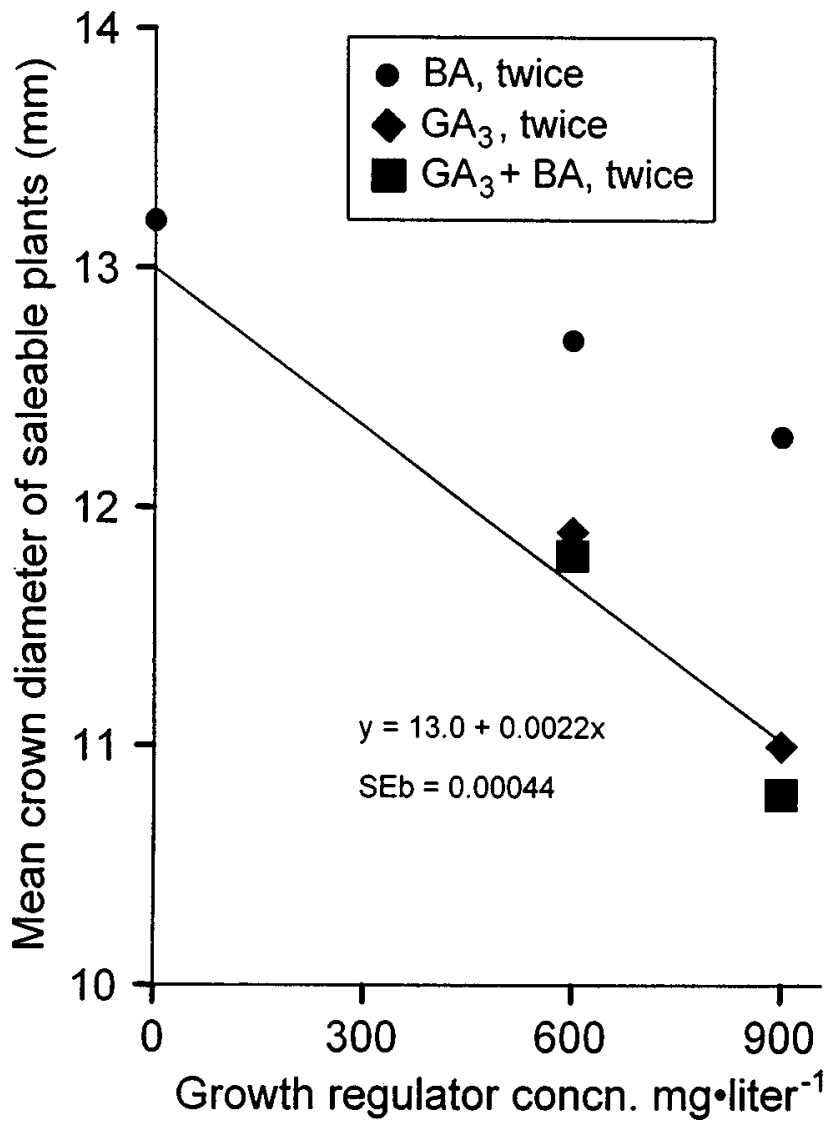

Fig. 4. Diameter of saleable plants of 'Selva' strawberry in field plots on 2 Oct. 1991 after treatment twice with $\mathrm{BA}$ and $\mathrm{GA}_{3}$ in various combinations (Expt. 4). The means for only $\mathrm{GA}_{3}$ twice or in combination with BA (common regression line) differ significantly from the other means. The diameters of plants treated with only BA did not differ from the nontreated controls.

Table 1. Means for two characteristics of 'Selva' strawberry plants following application of BA and GA in various combinations, once or twice, in 1992 (Expt. 5).

\begin{tabular}{|c|c|c|c|}
\hline \multicolumn{2}{|c|}{ Growth regulator } & \multirow{3}{*}{$\begin{array}{c}\text { Runner plants/ } \\
\text { mother plant } \\
\text { (total no.) }\end{array}$} & \multirow{3}{*}{$\begin{array}{c}\text { Crown } \\
\text { diam } \\
(\mathrm{mm}) \\
\end{array}$} \\
\hline $\mathrm{BA}$ & $\mathrm{GA}_{3}$ & & \\
\hline \multicolumn{2}{|c|}{$\left(\right.$ a.i., $\left.\mathrm{mg} \cdot \mathrm{L}^{-1}\right)$} & & \\
\hline$\overline{0}$ & 0 & 24.9 & 11.6 \\
\hline 900 & & 31.3 & 11.0 \\
\hline 1200 & & 30.8 & 10.4 \\
\hline 900 & 100 & 32.1 & 10.6 \\
\hline 1200 & & 32.3 & 10.3 \\
\hline 900 & 300 & 35.0 & 10.0 \\
\hline 1200 & & 34.7 & 10.5 \\
\hline \multicolumn{4}{|c|}{ Significance levels ( $P$ values $)$} \\
\hline Nor & other treatments & 0.0001 & 0.0005 \\
\hline BA & & 0.8800 & 0.6100 \\
\hline GA & & 0.0140 & 0.1700 \\
\hline GA & & 0.9200 & 0.7800 \\
\hline BA & linear & 0.9600 & 0.0690 \\
\hline $\mathrm{BA}$ & residual & 0.8200 & 0.9800 \\
\hline
\end{tabular}

Table 2. Various characteristics of 'Selva' runner plants after being sprayed once or twice with diverse combinations of BA and $\mathrm{GA}_{3}$ in 1992 (Expt. 5).

\begin{tabular}{|c|c|c|c|c|}
\hline \multirow[b]{2}{*}{ Sprays } & \multicolumn{4}{|c|}{ Plant characteristics } \\
\hline & $\begin{array}{c}\text { Saleable/ } \\
\text { mother plant } \\
\text { (no.) }\end{array}$ & $\begin{array}{c}\text { Runner plants/ } \\
\text { mother plant } \\
\text { (total no.) }\end{array}$ & $\begin{array}{l}\text { Crown } \\
\text { diam } \\
(\mathrm{mm})\end{array}$ & $\begin{array}{c}\text { Saleable } \\
(\%)\end{array}$ \\
\hline Once & 14.7 & 30.5 & 10.9 & 48 \\
\hline Twice & 12.2 & 32.7 & 10.4 & 38 \\
\hline Probability & 0.0029 & 0.069 & 0.034 & 0.0001 \\
\hline
\end{tabular}

and growth regulator treatments. When the plants were sprayed with growth regulators twice more plants were formed, but a smaller percentage was saleable because they had smaller diameters than when sprayed once. This result is consistent with increased plant density giving smaller diameter plants.

All plants treated once with PGRs were similar in their total marketable yield, total yield, and mean berry weight to the nontreated control (data not shown).

Experiment 5a. Plants sprayed with BA and $\mathrm{GA}_{3}$ combined had more saleable runner plants and more of them in total than the controls, as did plants treated only with $\mathrm{GA}_{3}$ at $300 \mathrm{mg} \cdot \mathrm{L}^{-1}$ (Tables 3 and 4).

The diameter of the runner plants was significantly affected by the BA treatments only. Diameters decreased with increased BA dosage, 11.5, 10.4, and $10.6 \mathrm{~mm}$ for 0,900 , and $1200 \mathrm{mg} \cdot \mathrm{L}^{-1}$, respectively.

\section{Discussion}

The synergistic combination of $\mathrm{GA}_{3}$ and BA consistently enhanced runner production in dayneutral strawberries. This result agrees with those of Kender et al. (1971) and Waitlaka and Dana (1978), who had similar results with the everbearing strawberries 'Geneva' and 'Ozark Beauty'.

Plants treated with $\mathrm{GA}_{3}$ and higher BA concentrations produced more runners than plants receiving other treatments. Our results suggest that doses of BA at $1800 \mathrm{mg} \cdot \mathrm{L}^{-1}$ might further increase runner formation. Braun and Kender(1985) did not observe improved runner production when they used BA at $50 \mathrm{mg} \cdot \mathrm{L}^{-1}$ applied five times at weekly intervals. This result agrees with those of Pritts et al. (1986) that one high dose of BA is more effective than a low dose applied repeatedly.

There is an optimum dosage for $\mathrm{GA}_{3}$ when used in combination with BA. Higher $\mathrm{GA}_{3}$ doses increased runner production but caused significant internode elongation, which was detrimental to the development of runner plants as they often did not root in the field. Previous research showed that repeated doses of $\mathrm{GA}_{3} 50$ $\mathrm{mg} \cdot \mathrm{L}^{-1}$ stimulated runners to be produced in everbearing cultivars (Braun and Kender 1985; Kender et al., 1971; Waitlaka and Dana 1978). We found that $\mathrm{GA}_{3}$ between 100 to $300 \mathrm{mg} \cdot \mathrm{L}^{-1}$ produce acceptable results in dayneutral cultivars.

Repeated applications of PGRs appeared to be of little or no value under the environmental conditions of these trials because a second application either had no effect or reduced the yield of runner plants. However, in Expt. 5, the second dose produced more smaller runners that were not saleable. With a longer growing season, these could become larger and eventually reach acceptable standards. Other researchers have used repeated applications of $\mathrm{GA}_{3}$ and $\mathrm{BA}$, but did not compare them with single applications (Braun and Kender 1985; Kahangi et al., 1992; Kender et al., 1971; Waitlaka and Dana, 1978).

Carry-over effects of the treatment appear to be limited and may be beneficial. Flower 
Table 3. Significance levels for two characteristics for $\mathrm{BA}$ and $\mathrm{GA}_{3}$ applied in various combinations once to 'Selva' strawberry plants (Expt. 5a).

\begin{tabular}{|c|c|c|}
\hline \multirow[b]{2}{*}{ Effect } & \multicolumn{2}{|c|}{$\begin{array}{c}\text { Runner plants/ } \\
\text { mother plant }\end{array}$} \\
\hline & $\begin{array}{c}\text { No. } \\
\text { saleable }\end{array}$ & $\begin{array}{c}\text { Total } \\
\text { no. }\end{array}$ \\
\hline$\overline{\mathrm{BA}}$ - linear (lin) & 0.0003 & 0.7500 \\
\hline BA - quadratic (quad) & 0.4900 & 0.8000 \\
\hline $\mathrm{GA}_{3}-\operatorname{lin}$ & 0.0001 & 0.0001 \\
\hline $\mathrm{GA}_{3}-$ quad & 0.0001 & 0.0006 \\
\hline $\mathrm{BA}-\operatorname{lin} \times \mathrm{GA}_{3}-\operatorname{lin}$ & 0.0470 & 0.6800 \\
\hline $\mathrm{BA}-$ quad $\times \mathrm{GA}_{3}-\operatorname{lin}$ & 0.6800 & 0.4400 \\
\hline $\mathrm{BA}-\operatorname{lin} \times \mathrm{GA}_{3}-$ quad & 0.0280 & 0.0150 \\
\hline $\mathrm{BA}-$ quad $\times \mathrm{GA}_{3}-$ quad & 0.0008 & 0.0077 \\
\hline
\end{tabular}

Table 4. Means for two characteristics for BA and $\mathrm{GA}_{3}$ applied in various combinations once to 'Selva' strawberry plants (Expt. 5a).

\begin{tabular}{|c|c|c|c|}
\hline \multicolumn{2}{|c|}{ Growth regulator } & \multicolumn{2}{|c|}{ Runner plants/mother plant } \\
\hline $\mathrm{BA}$ & $\mathrm{GA}_{3}$ & \multirow{2}{*}{$\begin{array}{c}\text { No. } \\
\text { of saleable }\end{array}$} & \multirow{2}{*}{$\begin{array}{c}\text { Tota } \\
\text { no. }\end{array}$} \\
\hline \multicolumn{2}{|c|}{$\left(\right.$ a.i. $\left.\mathrm{mg} \cdot \mathrm{L}^{-1}\right)$} & & \\
\hline \multirow[t]{3}{*}{$\overline{0}$} & 0 & 12.8 & 19.8 \\
\hline & 100 & 13.9 & 31.5 \\
\hline & 300 & 16.1 & 37.7 \\
\hline \multirow[t]{3}{*}{900} & 0 & 10.4 & 12.2 \\
\hline & 100 & 19.4 & 38.7 \\
\hline & 300 & 18.1 & 36.8 \\
\hline \multirow[t]{3}{*}{1200} & 0 & 13.5 & 26.7 \\
\hline & 100 & 17.6 & 34.2 \\
\hline & 300 & 20.2 & 36.9 \\
\hline 0 & Mean & 14.3 & 33.0 \\
\hline 900 & & 15.9 & 32.9 \\
\hline 1200 & & 17.1 & 32.4 \\
\hline \multirow[t]{3}{*}{ Mean } & 0 & 12.2 & 26.6 \\
\hline & 100 & 17.0 & 34.8 \\
\hline & 300 & 18.1 & 36.9 \\
\hline
\end{tabular}

bud initiation begins again shortly after the application of the PGRs. In Expt. 4, there also was a slight increase in fruit yield and berry size from the runner plants when grown in production fields in Florida. This response has not been documented previously.

The combination of $\mathrm{GA}_{3}$ and BA reliably induced runner formation in dayneutral strawberries. We suggest that $\mathrm{GA}_{3}$ at 300 and $\mathrm{BA}$ at $1200 \mathrm{mg} \cdot \mathrm{L}^{-1}$ is a suitable compromise. This treatment will be useful for plant propagators and plant breeders who wish to increase the runner production of dayneutral strawberries.

\section{Literature Cited}

Archbold, D.D. and J.G. Strang. 1986. Effect of BA on growth and yield of 'Redchief' strawberry. HortScience 21:1377-1379.

Braun, J.W. and W.J. Kender. 1985. Correlative bud inhibition and growth habit of the strawberry as influenced by application of gibberellic acid, cytokinin, and chilling during short daylength. J. Amer. Soc. Hort. Sci. 110:28-34.

Cameron, J.S., J.F. Hancock, and T.M. Nourse. 1985. The field performance of strawberry nursery stock produced originally from runners or micropropagation. Adv. Strawberry Prodn. 4:5658.

Dale, A. and A. Vandenberg. 1989. Guidelines. Ontario strawberry plant propagation program.
Ont. Min. of Agr. and Food, Hort. Res. Inst. of Ont., Vineland Sta.

Elfving, D.C. and O.B. Allen. 1987. Effect of Gibberellin $\mathrm{A}_{4+7}$ applications on 'Golden Delicious' Fruit Russet. Crop Res. 27:11-18.

Kahangi, E.M., Y.Fujime, and E. Nakamura. 1992. Effects of chilling and growth regulators on runner production of three strawberry cultivars under tropical conditions. J. Hort. Sci. 67:381384.

Kender, W.J., S. Carpenter, and J.W. Braun. 1971. Runner formation in everbearing strawberry as influenced by growth-promoting and inhibiting substances. Ann. Bot. 35:1045-52.

Pritts, M.P. and A. Dale. 1989. Dayneutral strawberry production guide. Cornell Coop. Ext. Info. Bul., Ithaca, N.Y.

Pritts, M.P., G.S. Posner, and K.A.Worden. 1986. Effects of 6-BA application on growth and development of 'Tristar', a strong day-neutral strawberry. HortScience 21:1421-1423.

Reid, J.H. 1983. Practical growth regulator effects on strawberry plants-a review. Crop Res. 23:113120.

Scott, D.H., G.J. Galletta, and H.J. Swartz. 1985. Tissue culture as an aid in the propagation of 'Tribute' everbearing strawberry. Adv. Strawberry Prodn. 4:59-60.

Waithaka, K. and M.N.Dana. 1978. Effects of growth substances on strawberry growth. J. Amer. Soc. Hort. Sci. 103:627-628. 